\title{
Effectiveness of Moringa Oleifera and Poly Aluminum Chloride Leaves in Peat Organic Substances in Rasau Jaya Village, Kubu Raya Regency
}

\author{
Gervacia Jenny. $\mathbf{R}^{1, a,{ }^{*}}$, Maulidiyah Salim ${ }^{1, b}$ \\ ${ }^{1}$ Department of Health Analyst Poltekkes Kemenkes Pontianak, Jalan Dr. Sudarso, Pontianak, Indonesia \\ a,* prodi_d4analis@yahoo.co.id (Corresponding Author) \\ ${ }^{\mathrm{b}}$ maulidiyahsalim@gmail.com
}

\begin{abstract}
One source of surface waters in West Kalimantan is peat water that has low turbidity, dark brown to black (124 850 units of PtCo), high organic content $(138-1560 \mathrm{mg} / \mathrm{L}$

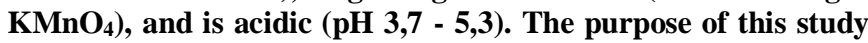
is to determine the effect of the addition of PAC and Moringa Oleifera leaves to the decrease in levels of peat organic water in the Rasau Jaya Village area, Kubu Raya Regency. The method used in this research is by mixing Moringa leaf powder and PAC (Poly Aluminum Chloride) in peat water accompanied by stirring and precipitating. Furthermore, peat water samples were analyzed for their organic content using the permanganometric titration method. The results showed that the levels of organic substances in peat water before the addition of PAC and Moringa leaf powder amounted to $176.96 \mathrm{mg} / \mathrm{l}$, after the addition of $125 \mathrm{mg}$ PAC and Moringa leaf powder with concentrations of $25,50,75 \mathrm{l}, 100,125,150,175,200 \mathrm{mg} / \mathrm{l}$, respectively: $42.04 \mathrm{mg} / \mathrm{l}, 46.97 \mathrm{mg} / \mathrm{l}, 58.14 \mathrm{mg} / \mathrm{l}, 66.15 \mathrm{mg} / \mathrm{l}$, 67.20 mg/l, 60.25 mg/l, 63.41 mg/l, and 53.07 mg/l. Based on the results through regression statistical tests obtained sig $=0.015$ $<0.05$ which means $\mathrm{Ha}$ is accepted that there is an effect of increasing the concentration of Moringa oleifera powder and PAC on Organic Content in Peat Water in Rasau Jaya Village, Kubu Raya Regency.
\end{abstract}

Keywords-Peat Water, Moringa Oleifera, Poly Aluminum Chloride, Organic matter

\section{Introduction}

Kubu Raya Regency is a relatively flat plain area with a slope of land $0-3 \%$ covering 792,320 Ha, slope area $3-15 \%$ covering 7,205 $\mathrm{Ha}$ and slope above $40 \%$ covering $850 \mathrm{Ha}$. The total area of the sea is $2,197 \mathrm{~km}^{2}$ of the total area of the regency, which is $6,982.20 \mathrm{~km}^{2}$. Based on the division of physiographic areas, namely an area that has almost the same physical and geographical characteristics, the Kubu Raya region is included in the physiographic unit area of the Kapuas
Coastal Swamp Plain, which is also called peat landform, which is landform formed in swampy areas with a fairly thick accumulation of organic material [1].

Organic matter in peat water is dominated by humid substances which have molecular weights of up to 100,000 Dalton (Da) and are in the colloidal size range [2]. The measurements of the organic compounds present in peat water are difficult to separate.

In peatlands, surface water is available which is difficult to use as a source of raw water for daily needs. The surface water is yellow or brown in color and contains high organic matter and is acidic, so it needs to be treatment before use. Surface water in West Kalimantan has low turbidity, dark brown to black color (124 - 850 units of PtCo), high organic content $\left(138-1560 \mathrm{mg} / \mathrm{L} \mathrm{KMnO}_{4}\right)$, and is acidic (pH 3.7 - 5.3) [3].

The most common and economical processes for reducing high organic content are coagulation and flocculation processes. Coagulation and flocculation processes can use chemical coagulants, natural coagulants or a combination of chemical and natural coagulants. The research that has been done used extracts of Nirmali (Strychnoos Potatorum), M. oleifera seeds, Tamarind seeds (Tamarindus Indica) and Chitosan, as effective coagulants to reduce textile dyestuffs (red acid and orange acid) by 60 $80 \%$ [4] . The other research conducted a study that compared the use of Moringa leaves and alum as water purification agents which obtained optimal results on the use of Moringa leaf coagulant in reducing $\mathrm{Fe}$ and $\mathrm{Mn}$ [5]. 


\section{Research Methods}

\section{A. Material}

In general, Alum is mostly used as a coagulant. However, currently a new type of coagulant has been found with better performance than the use of alum coagulant, mentioned as Poly Aluminum Chloride (PAC). PAC has several advantages, including low corrosiveness, the resulting floc is easier to separate, and the $\mathrm{pH}$ of the treated water is not too low.
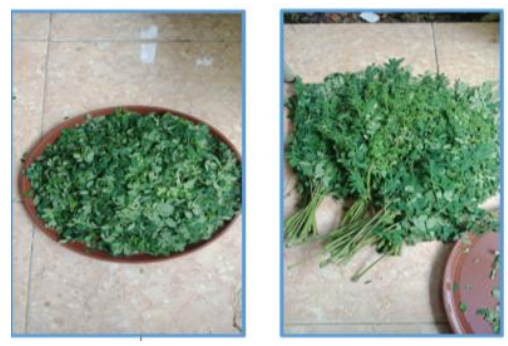

Figure 1. Moringa leaf

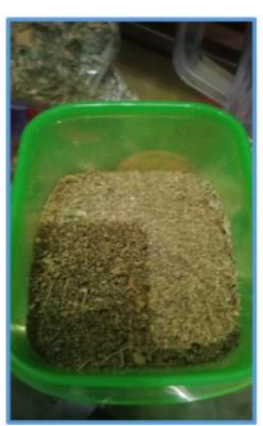

Figure 2. Moringa leaf powder

\section{B. Research Methodology}

The research design used in this study is experimental research. The population of this study was peat water obtained in the area of Rasau Jaya Village, Kubu Raya Regency, West Kalimantan. The peat water sample used in this study was added with PAC 125 $\mathrm{mg} / \mathrm{L}$, then Moringa leaf powder was added with various concentrations of $25 \mathrm{mg} / \mathrm{L}, 50 \mathrm{mg} / \mathrm{L}, 75 \mathrm{mg} / \mathrm{L}$, $100 \mathrm{mg} / \mathrm{L} ., 125 \mathrm{mg} / \mathrm{L}, 150 \mathrm{mg} / \mathrm{L} 175 \mathrm{mg} / \mathrm{L}$ and 200 $\mathrm{mg} / \mathrm{L}$.
Measurement of levels of organic matter in peat water is based on permanganate values. A total of 100 $\mathrm{mL}$ of peat water that had been added by PAC and Moringa leaf powder with various concentrations was put into a $300 \mathrm{~mL}$ Erlenmeyer and 3 boiling stones were added. After that, a solution of $0.01 \mathrm{~N} \mathrm{KMnO}_{4}$ is added a few drops to form a pink color. Then added $5 \mathrm{~mL}$ of $8 \mathrm{~N}$ solution $\mathrm{H}_{2} \mathrm{SO}_{4}$ free of organic substances and heated on an electric heater at a temperature of $105^{\circ} \mathrm{C} \pm$ $20^{\circ} \mathrm{C}$ (continued boiling if there is a smell of $\mathrm{H}_{2} \mathrm{~S}$ ). Next pipette $10 \mathrm{~mL} 0.01 \mathrm{~N}$ standard $\mathrm{KMnO}_{4}$ solution and reheated until boiling for 10 minutes.

Then pipetted back $10 \mathrm{~mL}$ of $0.01 \mathrm{~N}$ oxalic acid standard solution. Finally titrated with $0.01 \mathrm{~N} \mathrm{KMnO}_{4}$ to form a pink color. The volume of titration used is recorded [6].

\section{Results and Discussion}

This study is aimed to determine the effect of Moringa oleifera and PAC (Poly Aluminum Chloride) Leaves in Reducing Organic Content in Peat Water in Rasau Jaya Village, Kubu Raya Regency. The sample used amounted to 24 samples. Samples were treated with no Moringa leaf powder and PAC as a control and 25, 50, 75, 100, 125, 150, 175 and $200 \mathrm{mg} / \mathrm{l}$ of Moringa leaf powder and PAC were added.

\section{A. Descriptive Analysis}

Tabel 1. Descriptive Statistics Test

\begin{tabular}{|c|c|c|}
\hline Sample Code & Mean & $\begin{array}{c}\text { Standard } \\
\text { Deviation (SD) }\end{array}$ \\
\hline A & 176.9600 & 28.96199 \\
\hline C & 42.0400 & 2.48024 \\
\hline D & 46.9733 & 0.36950 \\
\hline E & 58.1400 & 4.42000 \\
\hline F & 66.1467 & 5.73723 \\
\hline G & 67.2000 & 2.63251 \\
\hline H & 60.2467 & 5.26101 \\
\hline I & 63.4067 & 4.06537 \\
\hline J & 53.0867 & 8.28753 \\
\hline
\end{tabular}

Based on table 1, it can be seen that there is a decrease in levels of organic substances before and after the addition of PAC and Moringa leaf powder. 


\section{B. Normality Test}

Furthermore, to investigate whether the data are normally distributed, the Normality Test was performed. Based on the results of the normality test data with the Shapiro-Wilk test obtained a significant value of $p(0.137)>0.05$ so it shows the data that are normally distributed.

\section{Bivariate Analysis}

Simple Linear Regression Test is used to investigate the effectiveness of the concentration of Moringa leaf powder and PAC on the levels of organic substances in peat water.

Table 2. Correlations

\begin{tabular}{|c|c|c|c|}
\hline \multicolumn{2}{|c|}{} & $\begin{array}{c}\text { Organic } \\
\text { Substance } \\
\text { Levels }\end{array}$ & Treatment \\
\hline \multirow{2}{*}{$\begin{array}{c}\text { Pearson } \\
\text { Correlation }\end{array}$} & $\begin{array}{c}\text { Organic } \\
\text { Substance } \\
\text { Levels }\end{array}$ & 1.000 & 0.492 \\
\cline { 2 - 4 } & Treatment & 0.492 & 1.000 \\
\hline \multirow{2}{*}{$\begin{array}{c}\text { Sig. } \\
(1-t a i l e d)\end{array}$} & $\begin{array}{c}\text { Organic } \\
\text { Substance } \\
\text { Levels }\end{array}$ & & 0.007 \\
\cline { 2 - 4 } & Treatment & 0.007 & \\
\hline \multirow{4}{*}{$\mathbf{N}$} & $\begin{array}{c}\text { Organic } \\
\text { Substance } \\
\text { Levels }\end{array}$ & 24 & 24 \\
\cline { 2 - 4 } & Treatment & 24 & 24 \\
\hline
\end{tabular}

Based on table 2, it can be seen that the relationship (correlation) between the addition of Moringa leaf powder and PAC with peat water organic matter content is $\mathrm{R}=0.492$. Positive sign on the correlation shows that there is an increase in levels of organic substances after the addition of Moringa leaf powder and PAC.

Anova Test is then performed to determine whether there is a significant (significant) effect of the independent variable on the dependent variable. Based on the ANOVA test, the significance/ probability value of $0.015<0.05$, which means that Ha was accepted so that it can be stated that there is an effect of increasing the concentration of Moringa oleifera powder and Poly Aluminum Chloride on Organic Substance Content in Peat Water in Rasau Jaya Village Regency of Kubu Raya.

Moringa leaves can be used to purify water because it contains nine amino acids, sucrose, D-Glucose, Alkaloids, Candles, Quercetin and Kaempferat are also rich in potassium and calcium [7].
Besides the leaves and roots contain lots of protein compounds, vitamins, alkalis, amino acids, and carbohydrates that can also be used as medicine [8]. Moringa leaf powder can be used as a coagulant in the coagulation process because of the protein content contained in these leaves which acts as a polyelectrolyte.

Protein in Moringa leaf powder in the form of amino acids is able to adsorb and form bonds between peat water particles and amino acids to form bonds that are stable and precipitate [9]. In this study the best results were obtained in reducing the concentration of organic substances using Moringa leaf powder and PAC with a mass of $25 \mathrm{mg}$ with an initial concentration of organic substances $176.96 \mathrm{mg} / \mathrm{l}$ to $42.04 \mathrm{mg} / \mathrm{l}$. This is due to organic substances in peat water which are reducing in nature have reacted with ammonium cations from cationic proteins contained in Moringa leaf powder. In this process cationic protein in Moringa leaf powder interacts with organic substances in peat water to form colloidal particles [8].

On the addition of PAC and Moringa leaf powder above $25 \mathrm{mg} / \mathrm{l}$ levels of organic substances tend to increase. The addition of coagulants is the addition of cations to neutralize the negative charge of colloidal particles in water so that the Van der Waals force occurs, so that colloidal particles flocculate. On the addition of PAC and Moringa leaf powder above 25 $\mathrm{mg} / \mathrm{l}$ the caption is released too much more than needed by colloidal particles in negatively charged water to form floc.

As a result, there will be excessive absorption of cations by colloidal particles in water so that colloidal particles will be positively charged and repulsion forces occur between particles, resulting in floc deflocation. Floc defoculation will cause the solution to become more turbid and organic substances to increase. In addition to the addition of Moringa leaf powder of more than $25 \mathrm{mg}$ the increase in concentration of organic substances is caused because the mass of the coagulant which exceeds the maximum coagulant no longer enlarges the size of the floc, because the floc is already in saturated condition. 


\section{Conclusions}

The conclusions of this study are:

1. Average levels of organic matter in peat water before the addition of PAC and moringa leaf powder at $176.96 \mathrm{mg} / \mathrm{l}$. Average levels of organic substances after the addition of PAC $125 \mathrm{mg}$ and Moringa leaf powder at $53.07 \mathrm{mg} / \mathrm{l}$ with the average $\mathrm{Fe}$ content of $0.48 \mathrm{mg} / \mathrm{l}$ in old Lemiding.

2. The results of computerized data processing through statistical regression tests obtained sig $=0.015<0.05$ which means $\mathrm{Ha}$ is accepted so that it can be stated that there is an effect of increasing the concentration of Moringa oleifera leaf powder and PAC on Organic Substance Content In Peat Water in Rasau Jaya Village, Kubu Raya Regency.

\section{References}

[1] Anonim, "Rencana Pembangunan Jangka Panjang (RPJP) Pemerintah Kabupaten Kubu Raya 2009-2029", (Kubu Raya Regency Government Long Term Development Plan 2009-2029). 2009.

[2] Leenheer, "Characterizing aquatic dissolved organic matter," Environ. Sci. Technol., vol. 37(1), p. 18A-26A, 2005.

[3] I. R. Eri and W. Hadi, "Kajian Pengolahan Air Gambut Menjadi Air Bersih Dengan Kombinasi Proses Upflow Anaerobic Filter Dan Slow Sand Filter", (Study of Peat Water Treatment into Clean Water With a Combination of Upflow Anaerobic Filter and Slow Sand Filter Process), Jurusan Teknik Lingkungan FTSP-ITS. no. 416, pp. 1-11, 2010

[4] Vasudevan, D. and Gopalakrishna, K, " Coagulation using ecofriendly natural coagulants", Sustainable Environmental Sanitation And Water Services, Loughborough University Institutional Respitory, Calcutta, India, 2002.

[5] T. S. Widyaningsih, "Pemanfaatan Daun Kelor (Moringa Oleifera) dan Tawas Sebagai Bahan Penjernih Air Sumur Gali", Utilization of Moringa Leaves (Moringa Oleifera) and Alum as Materials for Purifying Dug Well Water), J. Rekayasa Lingkung., vol. 15, no. 2, pp. 1-11, 2015.

[6] SNI, "Air dan air limbah - Bagian 22: Cara uji nilai permanganat secara titrimetri", (Water and wastewater Part 22: How to titrimetrically test permanganate values) 2004.

[7] A. Dudi Krisnadi, "Kelor Super Nutrisi", (Super Nutrient Moringa), Maret 2015. Blora: Pusat Informasi Dan Pengembangan Tanaman Kelor Indonesia, 2015.
[8] N. Sya'banah, "Efektivitas Ekstrak NaCl Biji Kelor (Moringa Oleifera) Sebagai Koagulan Sampel Fosfat", The Effectiveness of Moringa (Moringa Oleifera) Seed $\mathrm{NaCl}$ Extract As Phosphate Sample Coagulant), Universitas Islam Negeri Maulana Malik Ibrahim Malang, 2016.

[9] N. Ariati and K. Ratnayani, "Skrining Potensi Jenis Biji Polong-Polongan (Famili Fabaceae) dan Biji LabuLabuan (Famili Cucurbitaceae) Sebagai Koagulan Alami Pengganti Tawas", (Screening of Potential Types of Legumes (Fabaceae) and Pumpkin Seeds (Cucurbitaceae) as Natural Coagulant Substitutes for Alum), J. Kim., vol. 11, no. 1, pp. 15-22, 2017. 